\title{
Consórcio capim-braquiária e milho: comportamento produtivo das culturas e características nutricionais e qualitativas das silagens
}

\author{
Fernando de Paula Leonel ${ }^{1}$, José Carlos Pereira ${ }^{2}$, Marcone Geraldo Costa ${ }^{1}$, Paulo De Marco \\ Júnior ${ }^{3}$, Cássio José da Silva ${ }^{1}$, Luciano Aurélio Lara ${ }^{4}$
}

\author{
1 Programa de Pos-graduação em Zootecnia/UFV. \\ 2 Departamento de Zootecnia/UFV. \\ ${ }^{3}$ Laboratório de Ecologia Teórica e Síntese/DBG/ICB//UFG. \\ ${ }^{4}$ Consultor em Agropecuária.
}

RESUMO - Nesta pesquisa, o objetivo foi avaliar as diferenças entre silagens de culturas exclusivas ou do consórcio de milho e capim-braquiária, além de dois arranjos de semeadura do consórcio (duas fileiras de capim-braquiária nas entrelinhas do milho; e semeadura de capim-braquiária a lanço nas entrelinhas do milho). Avaliaram-se as produções de matéria seca (MS), proteína bruta (PB) e nutrientes digestíveis totais (NDT) por área e as características qualitativas das silagens (teores de PB, NDT, FDN, lignina e carboidratos não-fibrosos, nitrogênio amoniacal, ácidos butírico e lático e o pH). O milho em cultivo exclusivo, semeadura de duas fileiras do capim-braquiária nas entrelinhas do milho e semeadura do capim-braquiária a lanço nas entrelinhas do milho não diferiram com relação à produção de MS, PB e NDT, e nem com relação a variáveis qualitativas como teores de PB, NDT, FDN, lignina, pH, nitrogênio amoniacal, ácidos lático e butírico na MS das silagens, mostrando-se melhores desempenhos que o capim-braquiária em cultivo exclusivo quanto a essas variáveis. Porém, a recuperação do dossel forrageiro na área, após a colheita do material, foi mais rápida no arranjo com duas fileiras do capim-braquiária nas entrelinhas do milho.

Palavras-chave: agricultura, conservação de forragem, fermentação, integração, pecuária, recuperação de pastagens degradadas

\section{The intercrop between signal grass and corn: productive performance of the cultures, nutritional characteristics and silage quality}

\begin{abstract}
The objective of this work was to evaluate differences between silages produced from exclusive cultures or intercropped with corn and signal grass cultures in different sowing arrangements (two lines of signal grass in the corn inter-lines and hand-sowed signal grass in the corn inter-lines) The production of dry matter (DM), crude protein (CP) and total digestible nutrients (TDN) for area was evaluated, as well as the qualitative variables of DM in the silages including $\mathrm{CP}, \mathrm{TDN}, \mathrm{NDF}, \mathrm{LIG}, \mathrm{NFC}, \mathrm{NH}_{3}$, butyric and lactic acids and $\mathrm{pH}$. The corn in exclusive culture, signal grass in two lines and hand-sowed signal grass did not differ in relation to the DM, CP and TDN production or the qualitative variables in relation to the $\mathrm{CP}, \mathrm{TDN}, \mathrm{NDF}, \mathrm{LIG}, \mathrm{pH}, \mathrm{NH}_{3}$, butyric and lactic acid contents in the silage, showing better behavior than the signal grass exclusive culture. However, the canopy recovery in the area before harvest was faster in the two lines of signal grass in the corn inter-lines.
\end{abstract}

Key Words: agriculture, cattle, forage conservation, fermentation, intercrop, recuperation of degraded pastures

\section{Introdução}

Consumidores de produtos de origem animal se preocupam cada vez mais com a segurança alimentar, a responsabilidade social e, principalmente, a responsabilidade ambiental na aquisição desses produtos. Assim, é necessária a busca por sistemas de produção eficientes e com flexibilidade para se adequar a essas exigências e assegurar a competitividade aos produtores e a sustentabilidade sócio- ambiental. Nesse contexto, a integração agricultura e pecuária se destaca como opção por ser uma tecnologia moderna e conservacionista. Contudo, esse sistema exige a busca de maiores informações pelos produtores rurais para o sucesso da atividade.

A pecuária brasileira possui ainda vários entraves à produtividade, como a degradação das pastagens (Townsend et al., 2000; Oliveira et al., 2001a), a escassez de alimento volumoso e a perda do valor nutritivo desses 
alimentos para alimentação de bovinos durante o período seco do ano (Santos et al., 2004). Assim, o pecuarista, principalmente o pequeno produtor de leite precisa recuperar a produtividade da pastagem, bem como produzir e armazenar volumoso de boa qualidade para o período seco do ano. O cultivo de milho e forrageiras do gênero Brachiaria em consórcio pode ser a solução para esse problema.

Há relatos de que, na conservação de forragem por meio de ensilagem, deve-se preocupar com o padrão de fermentação do material ensilado. Essa atenção está relacionada ao fato de que o processo fermentativo de gramíneas perenes, caso do capim-braquiária, tem alguns entraves, como baixos teores de matéria seca e de carboidratos solúveis e elevado poder-tampão (Nussio, 2001; Reis \& Coan, 2001). O milho, por sua vez, é considerado padrão para ensilagem, em virtude de suas características fermentativas (Ferreira, 2001).

Desse modo, objetivou-se avaliar características produtivas e bromatológicas de silagens de milho cultivado na forma exclusiva e em consórcio com capim-braquiária.

\section{Material e Métodos}

As culturas foram estabelecidas em plantio direto sobre Argissolo Vermelho-Amarelo câmbico, em sucessão a pastagem degradada de capim-gordura (Melinis minutiflora). A fase de campo foi conduzida em Coimbra, Minas Gerais, área da Estação Experimental do Departamento de Fitotecnia da Universidade Federal de Viçosa (DFT/UFV). Antes da semeadura das culturas, foi realizado levantamento prévio da comunidade infestante, seguido da dessecação química das plantas daninhas com herbicidas sistêmicos (glyphosate $+2,4-D)$. A calagem de superfície foi realizada de maneira uniforme na área, com dose total de calcário, conforme resultados da análise química do solo: pH - 6,1; matéria orgânica - 3,41 dag/kg; fósforo $7,3 \mathrm{mg} / \mathrm{dm}^{3}$; potássio - $39 \mathrm{mg} / \mathrm{dm}^{3}$; cálcio - $2,9 \mathrm{cmol}_{\mathrm{c}} / \mathrm{dm}^{3}$; magnésio - $1,0 \mathrm{cmol}_{\mathrm{c}} / \mathrm{dm}^{3} ; \mathrm{H}+\mathrm{Al}-4,21 \mathrm{cmol}_{\mathrm{c}} / \mathrm{dm}^{3} ;$ e CTC $6,10 \mathrm{cmol}_{\mathrm{c}} / \mathrm{dm}^{3}$.

A semeadura das espécies consorciadas foi realizada com semeadora específica para plantio direto no dia 23 de novembro de 2003, sete dias após a dessecação das plantas daninhas. Na adubação de plantio, seguiram-se as recomendações básicas para a cultura do milho, sem adicional de adubo para cultura do capim-braquiária. $\mathrm{O}$ cultivar de milho (AGN 2012) foi semeado para se obter população de 50.000 plantas/ha, com espaçamento de $1 \mathrm{~m}$ entre linhas. O plantio do capim-braquiária, por meio de adaptação da semeadora, foi realizado nas entrelinhas do milho, em profundidade de 2 a $3 \mathrm{~cm}$, utilizando-se sementes puras viáveis de Brachiaria brizantha cv MG5 (2 a $3 \mathrm{~kg} / \mathrm{ha}$ ), em parcelas com 12 fileiras, espaçadas $1 \mathrm{~m}$ entre si. As adubações de cobertura e o manejo fitossanitário foram realizados conforme recomendações técnicas para a cultura do milho (Fancelli \& Dourado Neto, 2000).

As unidades experimentais (parcelas) tinham dimensões de $6 \mathrm{~m}$ (seis fileiras) de largura por $18 \mathrm{~m}$ de comprimento, resultando em uma área com $108 \mathrm{~m}^{2}$. As amostragens para estimativa da produção total (milho + capim-braquiária) por unidade de área e para determinação das características bromatológicas foram realizadas ceifando-se todo o material contido em $4 \mathrm{~m}$ (lineares) das duas fileiras centrais.

$\mathrm{O}$ delineamento experimental utilizado foi o inteiramente casualizado (área experimental total com características edáficas semelhantes), com arranjos espaciais de ambas as espécies: milho em cultivo exclusivo (MCE); capim-braquiária em cultivo exclusivo (BCE); semeadura de duas fileiras do capim-braquiária nas entrelinhas do milho (M+2FBEL); e semeadura do capim-braquiária a lanço nas entrelinhas do milho (M+BLAN). Cada arranjo de semeadura foi composto de quatro repetições. $\mathrm{O}$ material foi ensilado quando os grãos do milho se encontrava, no estágio intermediário da "linha do leite" com aproximadamente $30,5 \%$ de matéria seca.

O efeito dos arranjos de semeadura foi avaliado por meio de análise de variância de acordo com o modelo:

$$
Y_{i j}=\mu+a_{i}+e_{i j} \text {, }
$$

em que $\mathrm{Y}_{\mathrm{ij}}=$ observação referente à produção do $i$-ésimo arranjo, na $j$-ésima repetição; $\mu=$ constante inerente ao modelo; $\mathrm{a}_{\mathrm{i}}=$ efeito do $i$-ésimo arranjo de semeadura, com $i$ variando de 1 a 4 ; $\mathrm{e}_{\mathrm{ij}}=$ erro aleatório associado a observação, suposto normal e independentemente distribuído com média $=0$ (zero) e variância $\sigma^{2}$, ou seja, $\varepsilon_{\mathrm{ij}} \sim \mathrm{N}\left(0 ; \sigma^{2}\right)$. As médias dos arranjos foram comparadas pelo teste Student-Newman-Keuls, adotando-se o nível de 5\% de probabilidade.

Para confecção das silagens, o material oriundo das culturas foi picado em partículas de 2 a $3 \mathrm{~cm}$, colocado e adequadamente compactado em baldes de polivinil carbono, com capacidade para $5 \mathrm{~kg}$ de material fresco, nos quais foram adaptados flanges de silicone nas tampas para permitir o escoamento de gases. Após o enchimento, os baldes foram hermeticamente lacrados com fitas adesivas para evitar a troca de ar com o meio.

Os teores de matéria seca, proteína bruta, fibra em detergente neutro, extrato solúvel em éter, proteína insolúvel em detergente ácido e lignina em detergente ácido foram 
determinados de acordo com metodologia descrita por Silva \& Queiroz (2002). Uma fração de amostra de silagem de cada arranjo de semeadura foi prensada para extração do suco e determinação do $\mathrm{pH}$, utilizando-se potenciômetro digital (Digimed); do nitrogênio amoniacal/nitrogênio total $\left(\mathrm{N}-\mathrm{NH}_{3} / \mathrm{NT}\right)$, de acordo com as normas do AOAC (1995); e dos teores de ácido butírico, por cromatografia gasosa; e ácido lático, por cromatografia líquida de alta performance (HPLC), utilizando-se coluna de troca catiônica (Polyspher OA HY 51272; Merck, Amsterdam), de modo que a fase móvel consistiu de $\mathrm{H}_{2} \mathrm{SO}_{4}(0,004 \mathrm{~mol} / \mathrm{L})$ a uma taxa de $0,6 \mathrm{~mL} /$ minuto a $40^{\circ} \mathrm{C}$.

Os nutrientes digestíveis totais (NDT) foram estimados de acordo a equação adotada pelo NRC (2001):

$$
\mathrm{NDT}=\left[\mathrm{PBD}+(2,25 \mathrm{xAGD})+\mathrm{FDN}_{\mathrm{cp}} \mathrm{D}+\mathrm{CNFD}\right\rfloor-7
$$

em que: $\mathrm{PBD}=\mathrm{PB} \times \mathrm{EXP}^{[-1,2 \times(\mathrm{PIDAPB})]} ; \mathrm{AGD}=\mathrm{EE}=$ matéria solúvel em éter de petróleo, se $\mathrm{EE}<1 ; \mathrm{AG}=0$ $\left.\mathrm{FDN}_{\mathrm{cp}} \mathrm{D}=\left[0,75 \times\left(\mathrm{FDN}_{\mathrm{cp}}-\mathrm{LIG}\right)\right] \times 11-\left(\mathrm{LIG} / \mathrm{FDN}_{\mathrm{cp}}\right)^{0,667}\right]$, em que FDNcp = FDN corrigida para cinzas e proteína; $\mathrm{CNFD}=0,98 \times\{100-[(\mathrm{FDN}-\mathrm{PIDN})+\mathrm{PB}+\mathrm{EE}+\mathrm{CINZAS}]\} \times \mathrm{PAF}$, adotando-se PAF (fator de ajuste ao processamento) $=1$.

\section{Resultados e Discussão}

Verificou-se efeito dos arranjos de semeadura sobre a produção de forragem em matéria seca (PMS/ha). Os arranjos milho em cultivo exclusivo (MCE), milho com duas fileiras de capim-braquiária nas entrelinhas $(\mathrm{M}+2 \mathrm{FBEL})$ e milho com braquiária semeado a lanço nas entrelinhas (M+BLAN) não diferiram entre si $(\mathrm{P}>0,05)$ e foram superiores $(\mathrm{P}<0,05)$ ao capim-braquiária em cultivo exclusivo (Figura 1A).

A menor produtividade do capim-braquiária em cultivo exclusivo deve-se ao menor potencial produtivo de forrageiras perenes em relação às anuais, submetidas a apenas um corte. Os valores de produtividade do MCE, M+2FBEL e M+BLAN mantiveram-se entre a menor e maior produtividade de 30 cultivares de milho para ensilagem, estudados por Melo et al. (1999), de 12.490 a $20.590 \mathrm{~kg} / \mathrm{ha}$. Henrique et al. (1994) observaram produtividades de 8.500 a $14.000 \mathrm{~kg} / \mathrm{ha}$, enquanto Ghisi \& Pedreira (1987) comentam que o potencial produtivo anual das forrageiras do gênero de Brachiaria é de 6.000 a $36.000 \mathrm{~kg} / \mathrm{ha} / \mathrm{ano}$.

A similaridade entre a produtividade das culturas em consórcio e entre essas culturas e o MCE deveu-se à baixa produção do capim-braquiria nesses consórcios, por ocasião da ceifa, em relação à produção total de cada uma das formas de cultivo, pois a produção de matéria seca, somente do capim-braquiária nos consórcios, foi em torno de $800 \mathrm{~kg} / \mathrm{ha}$.

Os arranjos MCE, M+2FBEL e M+BLAN não diferiram $(\mathrm{P}>0,05)$ quanto ao teor de $\mathrm{PB}$ na MS das silagens e foram superiores ao BCE (Figura 1B), fato que também pode ser explicado pela baixa contribuição, em massa, do capimbraquiária na matéria seca total dos consórcios. Assim, o teor de PB na MS dessas silagens seguiram o padrão da silagem de milho, que, no trabalho realizado por Vilela (1985), variou de 4 a 7\% na MS quando as plantas foram ceifadas com 28 a 35\% de MS. Melo et al. (1999) obtiveram silagens de milho de 5,94 a 8,93\% de proteína bruta na matéria seca.

Oliveira et al. (2007) trabalharam com Brachiaria brizantha cv.Marandu em diferentes arranjos estruturais em sistema agrossilvipastoril com eucalipto e encontraram média de 6,16\% de PB na MS, enquanto Silva et al. (2005) trabalharam com silagem de Brachiaria brizantha cv. Marandu e observaram média de 9\% de PB.

A produção de proteína bruta por hectare não diferiu ( $P>0,05)$ entre os arranjos MCE, M+2FBEL e M+BLAN, que foram superiores $(\mathrm{P}<0,05)$ ao capim-braquiária em cultivo exclusivo (Figura 1C).

São poucos os trabalhos sobre avaliação da produção de PB por área. Em revisão de Evangelista et al. (2003) sobre silagens, há relatos de que o produto entre o teor de $\mathrm{PB}$ na MS e produção de MS/ha resulta em 727,6 kg de PB/ha oriundos de silagens de milho em cultivo exclusivo. Utilizando-se essa mesma metodologia com os dados de Evangelista et al. (1991), obtém-se $806 \mathrm{~kg}$ de PB/ha. Neste estudo, a produção de $\mathrm{PB}$ foi $843 \mathrm{~kg} / \mathrm{ha}$ nas silagens do milho em cultivo exclusivo.

Os teores médios de fibra (FDN) na MS das silagens dos arranjos MCE, M+2FBEL e M+BLAN não diferiram entre si $(\mathrm{P}>0,05)$ e foram inferiores $(\mathrm{P}<0,05)$ ao obtido com o capimbraquiária em cultivo exclusivo (Figura 1D).

A não-constatação de diferenças entre as silagens obtidas com os arranjos MCE, M+2FBEL e M+BLAN também deveu-se à baixa produtividade do capim-braquiária nos consórcios. Plantas de capim-braquiária possuem maior teor de fibra que plantas de milho no estádio fisiológico em que foram avaliadas. Nesse estádio, além das distinções entre as características anatômicas dos órgãos dessas forrageiras, existem as espigas de milho, que possuem elevados teores de carboidratos não-fibrosos e diluem esse teor de fibra. Vários trabalhos evidenciaram essa superioridade em FDN de silagens de capim-braquiária em relação a silagens de milho, Silva et al. (2005) encontraram silagem de Brachiaria brizantha com 75,95\% de FDN na MS. 

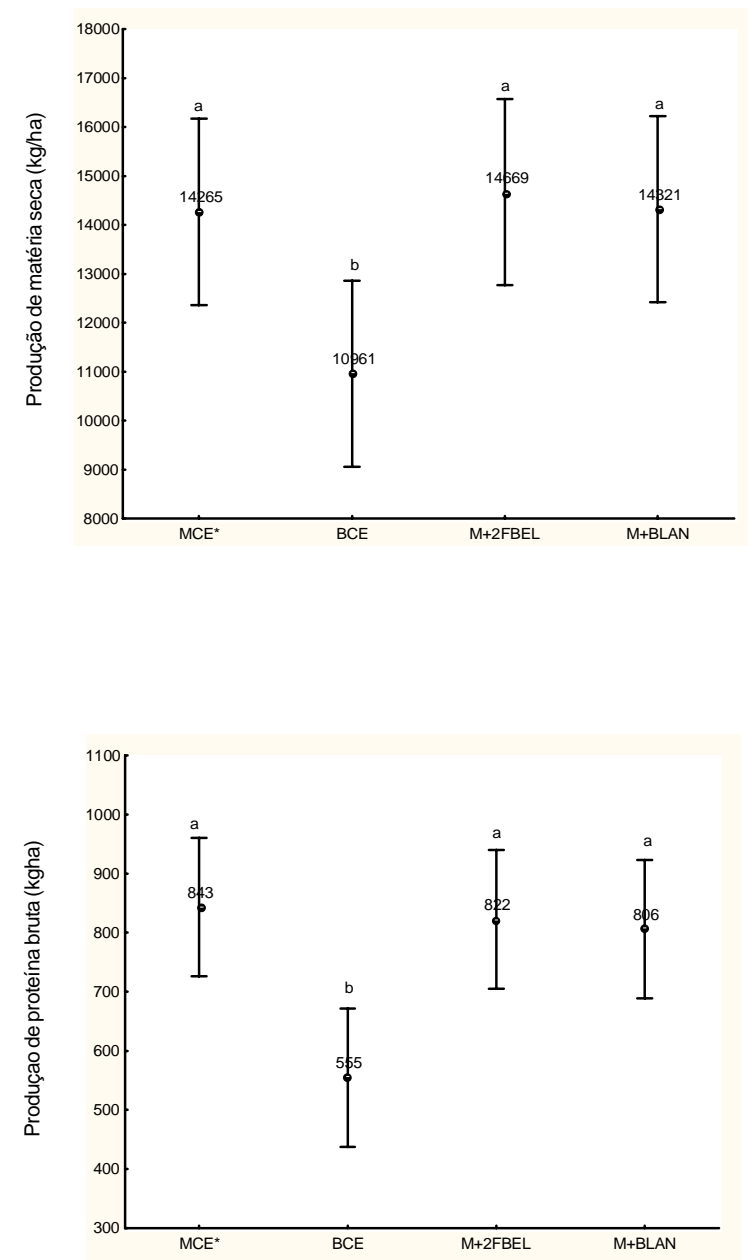

$\mathrm{E}$

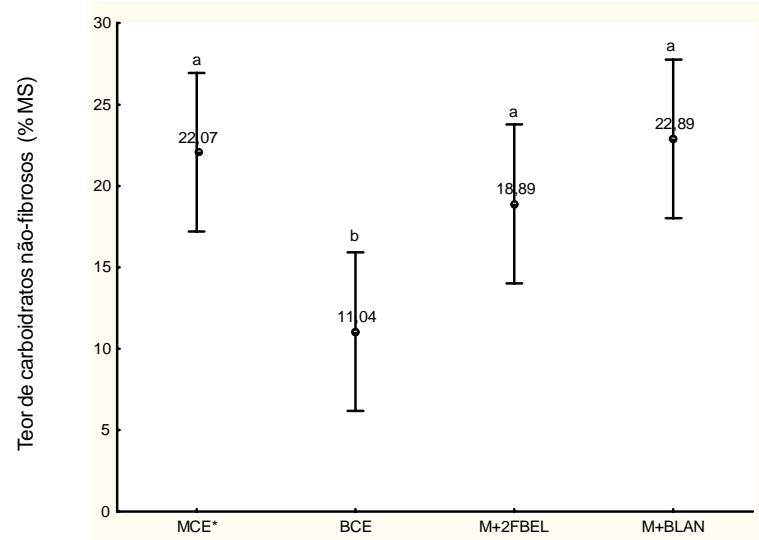

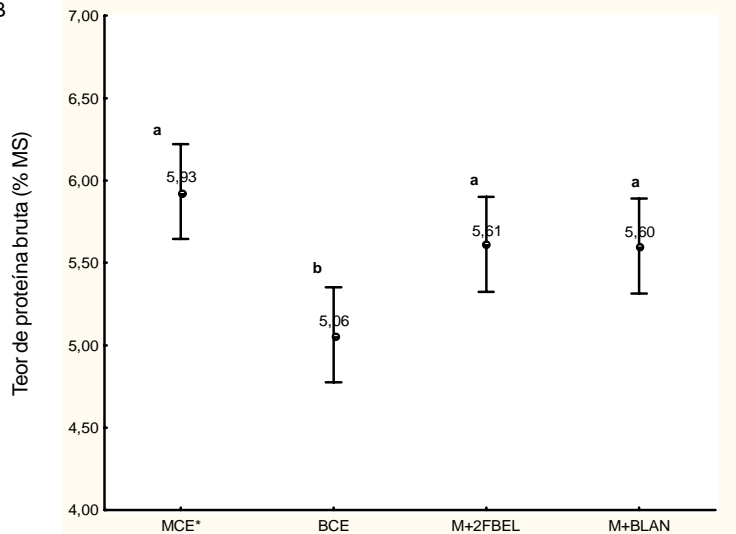
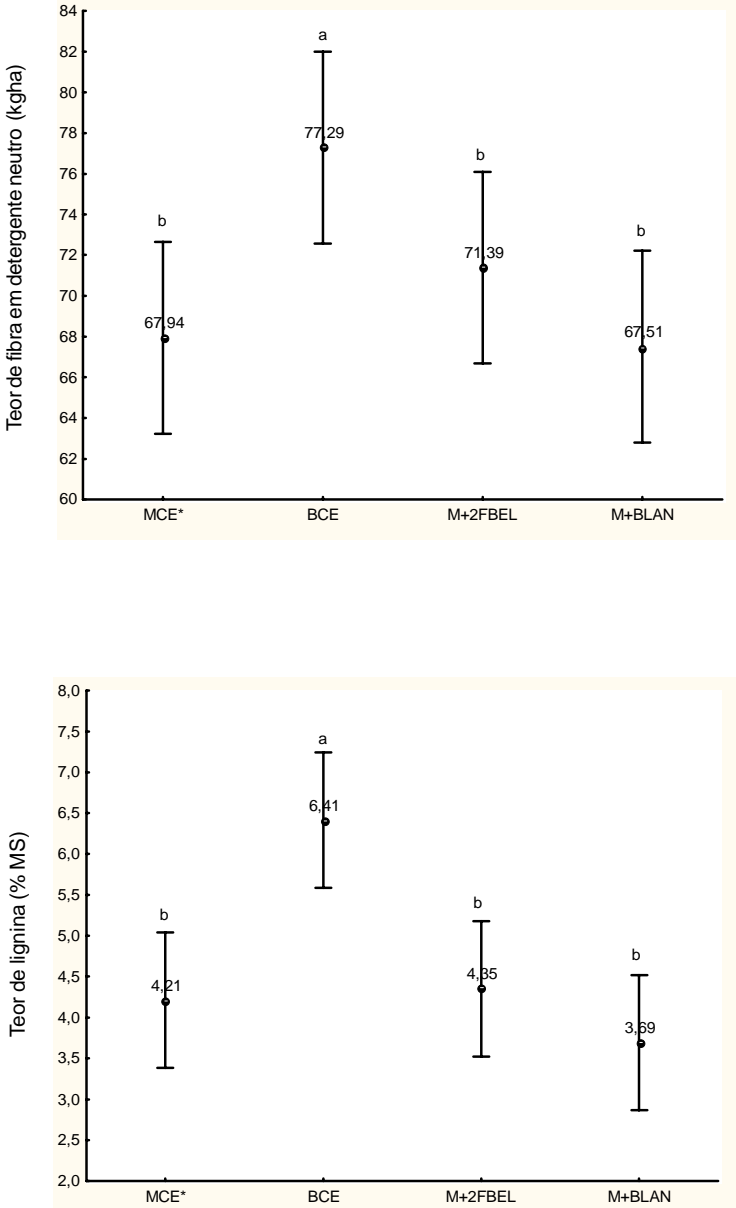

MCE = milho em cultivo exclusivo

$\mathrm{BCE}=$ capim-braquiária em cultivo exclusivo

$\mathrm{M}+2 \mathrm{FBEL}=$ duas fileiras do capim-braquiária nas entrelinhas do milho

$\mathrm{M}+\mathrm{BLAN}=$ capim-braquiária semeada a lanço nas entrelinhas do milho

Figura 1 - Produção de matéria seca, teores de proteína bruta, fibra em detergente neutro, carboidratos não-fibrosos, lignina na MS das silagens e produção de proteína bruta por hectare. As barras representam o intervalo de confiança de $95 \%$ e letras iguais indicam que os arranjos não diferiram entre si $(\mathrm{P}<0,05)$. 
Chizzotti et al. (2005), com 74,28\% e Cysneiros et al. (2006), $70 \%$. Melo et al. (1999) estudaram 30 cultivares de milho e obtiveram teor de FDN de 43,45 a 60,99\% na MS e Silva et al. (1999) encontraram valores de FDN de 61,05 a $71,18 \%$ da MS em estudo com 21 cultivares de milho.

$\mathrm{Na}$ análise da composição em carboidratos não-fibrosos (CNF) o teste de média revelou que o BCE foi inferior $(\mathrm{P}<0,05)$ aos demais arranjos, que não diferiram entre si $(\mathrm{P}>0,05)$ (Figura 1E).

A pouca contribuição em massa do capim-braquiária nos consórcios explica esse comportamento, pois na literatura é notória a superioridade em CNF de silagens de milho em comparação a silagens de capim-braquiária. Pina et al. (2006) trabalharam com silagens de milho e observaram 25,43\% de CNF na MS, Cabral et al. (2006) 31,27\% e Costa et al. (2005) 34,2\%. Em silagens de Brachiaria brizantha, Silva et al. (2005) encontraram média de 6,62\% de CNF na MS e Chizzotti et al. (2005), 10,30\%. Valores esses que correspondem, respectivamente, a 73 e $93 \%$ do teor de CNF encontrado nas silagens do BCE (Figura 1E).

Participam dos carboidratos não-fibrosos o amido, os açúcares monoméricos, os oligossacarídeos solúveis e os pectatos, frações de elevado aproveitamento energético pelos animais e, a maioria associada a boa preservação do material ensilado. A fração de carboidratos solúveis na forrageira a ser ensilada contribui para a rápida fermentação com produção de ácidos orgânicos, principalmente ácido lático, promovendo a estabilização da silagem (Murdoch et al., 1975).

O teor de lignina na MS das silagens do capim-braquiária em cultivo exclusivo foi maior $(\mathrm{P}<0,05)$ que nos demais arranjos, que não diferiram entre si $(\mathrm{P}>0,05)$ (Figura 1F).

A lignina está associada à indigestibilidade dos alimentos, entretanto, mais importante que seu teor é o seu arranjo estrutural na parede celular da forrageira (Jung $\&$ Deetz, 1993). Todavia, pesquisadores em nutrição animal tem abordado o teor de lignina em gramíneas tropicais como fração depreciativa dos alimentos.

Silva et al. (2005) registraram teores de 4,2\% de lignina na MS de silagens de milho; Pina et al. (2006), 3,2\%; Chizzotti et al. (2006), 4,73\%; e Wernersbach Filho et al. (2006), 4,02. Entretanto, Cavalcante et al. (2004) relatam silagens de milho com 6,0\% de lignina. Os teores médios de lignina nas silagens do MCE, do M+2FBEL e do M+BLAN mantiveram-se no intervalo dos valores supracitados (Figura 1F).

Em silagens de Brachiaria brizantha, Chizzotti et al. (2005) observaram teor de lignina de 10,08\% da MS; $57 \%$ superior ao do BCE, que, nesse estudo, foi de $6,41 \%$ desse composto, e Silva et al. (2005) encontraram média de $5,12 \%$, valor que representa $80 \%$ do encontrado no BCE (Figura 1F).

$\mathrm{O}$ teor de matéria seca do material ceifado do BCE foi inferior $(\mathrm{P}<0,05)$ ao dos demais arranjos. Entretanto, esses arranjos não diferiram entre si $(\mathrm{P}>0,05)$ com relação a essa variável (Figura 2A).

O teor de MS da planta para ensilagem está relacionado às condições de fermentação do material e aos níveis de perdas no sistema (Ferreira, 2001). Portanto, é usado para determinar o ponto adequado para ensilagem da forrageira. O ponto ideal para a ensilagem, que combina a ótima preservação do material com a maximização do valor nutritivo, é quando o teor de MS da forrageira situa-se na faixa de 28 a 35\% (McCullough, 1977), o que pode ser facilmente obtido em silagens de milho ou sorgo, porém, em gramíneas tropicais perenes, como as do gênero Brachiaria ssp. essa combinação é mais difícil. Para essas forrageiras, o máximo valor nutricional é atingido quando a planta possui teor de MS menor que o preconizado para ensilagem (Silveira et al., 1975).

O valor observado neste estudo foi $20 \%$ inferior ao encontrado por Silva et al. (2005) em estudo com Brachiaria brizantha cv. Marandu, média de 21,91\% de MS em plantas ensiladas com 100 a 110 dias pós-plantio. Ranjit \& Kung Jr. (2000) encontraram em silagens de milho 30,3 a 31,7\% e Magalhães et al. (2004), média de 28,57\%. São escassos os trabalhos que abordam o teor de MS de silagens confeccionadas com material oriundo de cultivo simultâneo de milho e capim-braquiária, porém o teor de MS, tanto das plantas de milho quanto de capim-braquiária obtidos neste estudo, estão em consonância com a maioria dos resultados citados na literatura.

$\mathrm{O}$ teor de nutrientes digestíveis totais (NDT) nas silagens do $\mathrm{BCE}$ foi inferior $(\mathrm{P}<0,05)$ aos encontrados nas silagens dos demais arranjos, que não diferiram entre si ( $P>0,05)$ (Figura 2B).

A composição em nutrientes digestíveis totais é indicativo do conteúdo energético dos alimentos e sua determinação em silagens ou qualquer alimento é imprescindível para o balanceamento e a otimização de dietas (Cappelle et al, 2001). A determinação dessa variável por meio da digestibilidade de cada nutriente é dispendiosa. Assim, atualmente, tem sido utilizada a equação de Weiss (1992), também adotada pelo NRC (2001) para essa estimativa. Utilizando essa metodologia, Pina et al. (2006) estimaram NDT em $62,88 \%$ da MS de silagens de milho, Obeid et al. (2006) 62,28\%, Rocha et al. (2006) 62,65\% e Costa et al. (2006) $62,5 \%$. O valor de NDT estimado nas silagens 
A

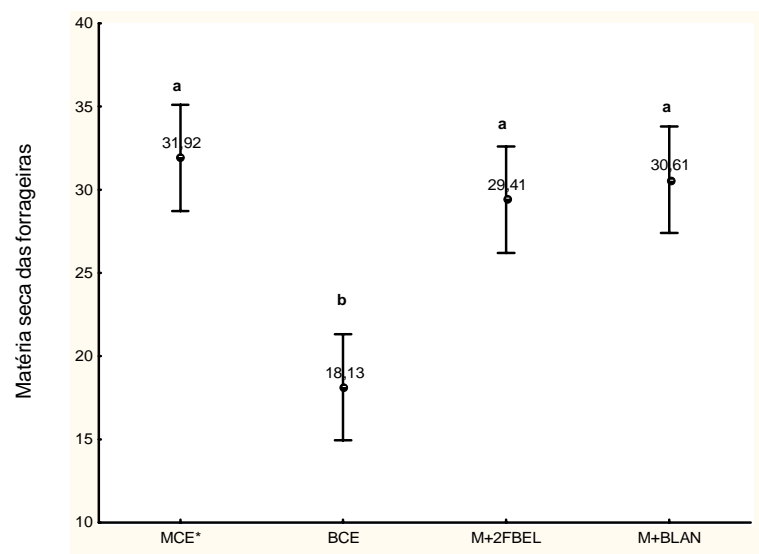

c

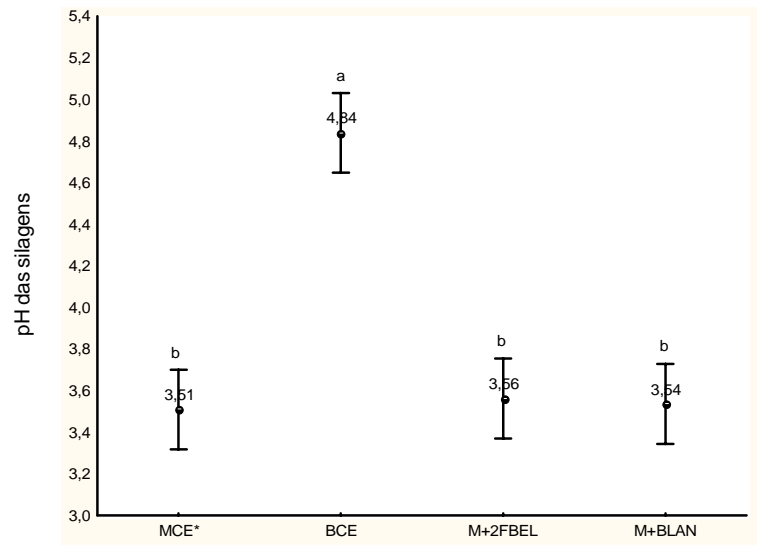

E

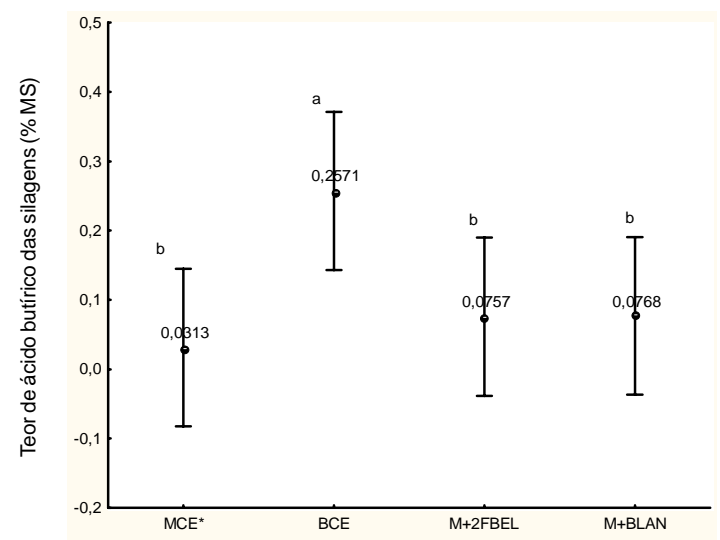

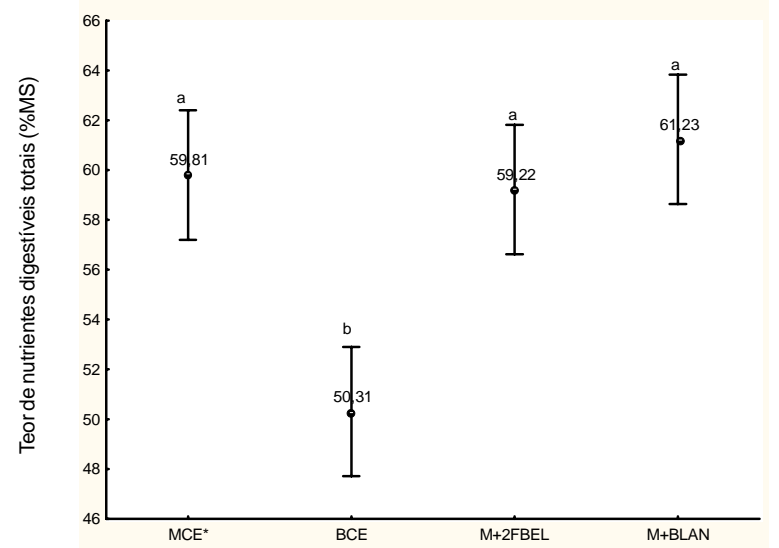

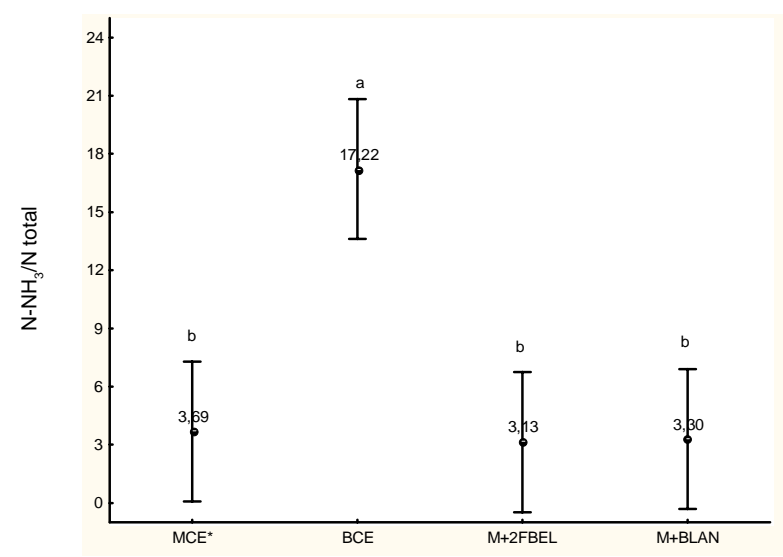

$\mathrm{F}$

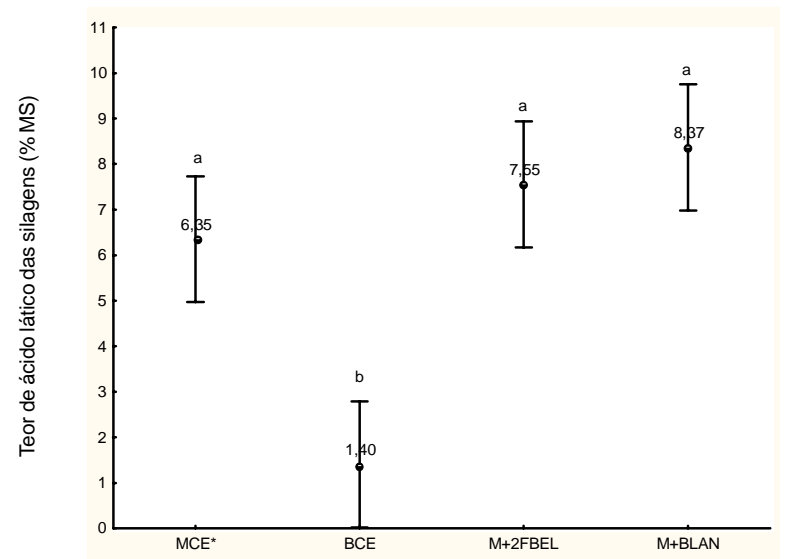

MCE = milho em cultivo exclusivo

$\mathrm{BCE}=$ capim-braquiária em cultivo exclusivo

M+2FBEL = duas fileiras do capim-braquiária nas entrelinhas do milho

M+BLAN = capim-braquiária semeada a lanço nas entrelinhas do milho

Figura 2 - Matéria seca, teor de nutrientes digestíveis totais, pH, nitrogênio amoniacal, ácidos butírico e lático na MS. As barras representam o intervalo de confiança de $95 \%$ e letras iguais indicam que os tratamentos não diferiram $(\mathrm{P}<0,05)$ entre si. As barras representam o intervalo de confiança de $95 \%$ e letras iguais indicam que os tratamentos não diferiram $(P<0,05)$ entre si. 
oriundas do MCE, do M+2FBEL e do M+BLAN foram iguais ou próximos aos da literatura (Figura $2 \mathrm{~B}$ ).

O valor de NDT observado neste trabalho (50,31\%) para as silagens do BCE foram próximos aos descritos por Silva et al. (2005) e Chizzotti et al. (2005), que encontraram teores de NDT de 51,56 e 48,85\%, respectivamente, em silagens de Brachiaria brizantha, cv. Marandu.

$\mathrm{O}$ pH médio das silagens do BCE foi superior $(\mathrm{P}<0,05)$ ao das silagens dos demais arranjos, os quais, não diferiram entre si $(\mathrm{P}>0,05)$ (Figura 2C).

Essa superioridade em $\mathrm{pH}$ nas silagens do arranjo BCE deve-se ao menor teor de carboidratos solúveis em plantas do gênero Brachiaria em comparação à de milho (Reis \& Coan, 2001) e, em razão da baixa contribuição em massa do capim-braquiária no M+2FBEL e no M+BLAN, não houve diferenças entre esses arranjos e o MCE.

A concentração adequada de carboidratos solúveis (CS) no material ensilado propicia condições favoráveis para estabelecimento e crescimento de bactérias do gênero Lactobacillus, que produzem o ácido lático. Esse ácido, por ser o mais "forte" entre os ácidos graxos produzidos no processo fermentativo de ensilagem, é desejável para proporcionar rápida estabilização do $\mathrm{pH}$ e melhor conservação do material ensilado (McDonald et al., 1991). Assim, o pH final da silagem é um dos indicativos da qualidade do processo fermentativo; e seu valor no interior do silo deve se tornar, o mais rápido possível, suficientemente baixo para inibir o desenvolvimento de bactérias indesejáveis, como as do gênero Clostridium (McDonald et al., 1991).

Segundo Ferreira (2001), silagens de milho e sorgo que passaram por adequada fermentação devem apresentar $\mathrm{pH}$ entre 3,8 e 4,2. Quando o pH atinge esses patamares, ocorre a inibição do crescimento de todos os microrganismos e a silagem atinge estabilidade (Rotz \& Muck, 1994).

Ranjit \& Kung Jr. (2000) registraram em silagens de milho pH de 3,66 a 3,73; e Rodrigues et al. (2004), de 3,76 a 4,38 , com média de 4,05. Neste trabalho, o pH médio das silagens dos materiais oriundas do MCE, do M+2FBEL e do M+BLAN (Figura 2C) foi inferior a 3,8; indicativo de que o material passou por adequada fermentação, preservando suas características nutricionais.

Para silagens de gramíneas perenes, Kung Jr. \& Shaver (2001) preconizam pH de no máximo 4,3 a 4,7. As silagens do capim-braquiária em cultivo exclusivo apresentaram $\mathrm{pH}$ acima do preconizado, indicativo de que a fermentação não foi adequada. Segundo Reis \& Coan (2001), pH acima de 4,7 em silagens dessas gramíneas pode estar relacionado a umidade elevada da forrageira na ocasião da ensilagem, a baixos teores de carboidratos fermentescíveis ou a elevada capacidade tampão dessas forrageiras.

Chizzotti et al. (2005) obtiveram silagens de Brachiaria brizantha com $\mathrm{pH}$ de 5,02; valor 3,58\% superior ao das silagens do BCE (Figura 2C). Cysneiros et al. (2006) trabalharam com silagens de Brachiaria brizantha e de Panicum maximum cv. (Tanzânia) e registraram, respectivamente, $\mathrm{pH}$ de 4,44 e 4,61.

$\mathrm{O}$ teor médio de $\mathrm{N}-\mathrm{NH}_{3} / \mathrm{NT}$ diferiu entre os arranjos e foi maior $(\mathrm{P}<0,05)$ nas silagens do BCE em comparação aos demais arranjos de semeadura, que não diferiram entre si (P>0,05) (Figura 2D).

$\mathrm{O}$ teor de $\mathrm{N}-\mathrm{NH}_{3} / \mathrm{NT}$ também é um indicativo de qualidade da silagem e auxilia na caracterização do perfil fermentativo ocorrido no processo. Quanto menor essa relação, menor a proteólise do material ensilado e de melhor qualidade será a silagem (McDonald et al., 1991). De acordo com Benacchio (1965), uma silagem é considerada como de muito boa qualidade quando possui concentração de $\mathrm{N}-\mathrm{NH}_{3}$ em relação ao nitrogênio total menor que $10 \%$. Se a concentração foi de 10 a $15 \%$ é considerada adequada, de 15 a $20 \%$, aceitável e superior a $20 \%$, insatisfatória.

Rocha et al. (2006) determinaram valores de ${\mathrm{N}-\mathrm{NH}_{3} /}^{\prime}$ Ntotal em silagens de milho, que variaram de 6,96 a 7,61 e Higginbotham et al. (1998), 6,7 a 8,9\%. Neste estudo, nas silagens oriundas dos arranjos MCE, M+2FBEL e M+BLAN, mensuraram-se valores de $\mathrm{N}-\mathrm{NH}_{3} /$ Ntotal, respectivamente, em 3,69; 3,13 e 3,30\% do $\mathrm{N}$ total, indicativo de que passaram por adequado processo fermentativo. Nas silagens obtidas com o BCE, a média foi de 17,22 de $\mathrm{N}-\mathrm{NH}_{3} / \mathrm{Ntotal}$, valor superior ao preconizado para silagem de boa qualidade. $\mathrm{O}$ maior teor de nitrogênio amoniacal nas silagens do BCE deve-se ao menor conteúdo de carboidratos prontamente fermentescíveis, ao menor teor de MS e à maior capacidade tampão, característicos em gramíneas forrageiras perenes.

Chizzotti et al. (2005) utilizaram Brachiaria brizantha e sorgo e obtiveram valores de $\mathrm{N}-\mathrm{NH}_{3} / \mathrm{Ntotal}$ de 21,18 e $6,42 \%$, respectivamente, para as silagens dessas duas forrageiras. Esses autores avaliaram o consumo dessas silagens isoladamente e em diferentes relações (33:67 e 67:33 - sorgo:capim-braquiária) entre as duas. Verificaram maior consumo da silagem de sorgo e correlação positiva entre porcentagem dessa silagem no volumoso total e o consumo de MS. Em silagens de capim-tanzânia, sem aditivos, Corrêa \& Cordeiro (2000) obtiveram concentrações de 11 a $19 \%$ de $\mathrm{N}-\mathrm{NH}_{3} /$ Ntotal. Tosi et al. (1999) registraram valores de $\mathrm{N}-\mathrm{NH}_{3} / \mathrm{N}$ total em 25,2 e $16,2 \%$ para silagens de capim-elefante fresco ou emurchecido por 24 horas. 
Os valores de ácido butírico nas silagens do BCE foram superiores $(\mathrm{P}<0,05)$ aos encontrados nas silagens dos demais arranjos de semeadura, que não diferiram entre si $(\mathrm{P}>0,05)$ (Figura 2E).

O ácido butírico é indicativo da qualidade do material ensilado e sua concentração está relacionada a fermentação indesejável, produto principalmente do trabalho de bactérias do gênero Clostridium (McDonald et al., 1991). Segundo Silveira (1975), a concentração desse ácido na MS da silagem deve ser inferior a 0,2\%. Ferreira (2001), para silagens de milho e sorgo, preconiza concentração inferior a $0,1 \%$ na MS.

Neste estudo, os teores de ácido butírico das silagens obtidos com MCE, M+2FBEL e M+BLAN foram abaixo do recomendado por Ferreira (2001) (Figura 2E), ou seja, valores desejados para se obter silagens de boa qualidade. Entretanto, nas silagens provenientes do BCE, registrou-se teor médio de $0,26 \%$ desse ácido, valor indesejado.

Ranjit \& Kung Jr. (2000) trabalharam com silagens de milho e encontraram valores de ácido butírico que variaram de 0,05 a 0,07\% da MS. Possenti et al. (2005) obtiveram média de $0,01 \%$ e Rodrigues et al. (2002), 0,07 a $0,20 \%$ com média de $0,14 \%$ desse ácido, na MS de silagens de milho.

Krizsan \& Randby (2006) trabalharam com silagens de pasto composto de capim-timótio (Phleum pratense), festuca (Festuca pratensis) e trevo (Trifolium pratense), e obtiveram valores de ácido butírico com média igual a $0,6 \%$ da MS, mínimo 0,0 e máximo 2,51\%. Ferrari Jr. \& Lavezzo (2001) utilizaram capim-elefante e registraram 0,20 e 0,18\% desse ácido na MS, respectivamente, de silagem de capim ensilado fresco ou emurchecido.

Para o ácido lático, houve diferença entre os arranjos de semeadura e as silagens do BCE; na média, apresentaram menores concentrações $(\mathrm{P}<0,05)$ desse ácido orgânico. Entretanto, não houve diferença entre os outros arranjos (P>0,05) (Figura 2F).

No processo de armazenamento de forragens verdes, por meio da ensilagem, é desejável que ocorra a proliferação de bactérias homoláticas, principalmente aquelas do gênero Lactobacillus. Essa busca tem o objetivo, entre outros, de aumentar a concentração de ácido lático no material ensilado e acelerar a queda do $\mathrm{pH}$ no interior do silo para diminuir as perdas por efluentes e, também, melhorar o desempenho dos animais (McDonald et al., 1991). Apesar de todos os ácidos orgânicos resultantes da fermentação contribuírem para a redução do $\mathrm{pH}$, o lático possui maior constante de dissociação iônica, o que o torna fundamental nesse processo (Moisio \& Heikomen, 1994). Assim, a concentração final de ácido lático na silagem é um indicador qualitativo da fase fermentativa da ensilagem. Silagens de milho são consideradas de boa qualidade quando possuem pelo menos de 6 a $8 \%$ de ácido lático na MS (Oliveira, 2001).

Nas silagens oriundas de MCE, M+2FBEL e M+BLAN, as concentrações de ácido lático na matéria seca foram, respectivamente, de 6,35; 7,55 e 8,37\% (Figura 2F), o que credencia todas como de boa qualidade. Entretanto, do BCE obtiveram-se silagens com 1,40\% desse ácido na MS, indicativo de fermentação inadequada do material. Possenti et al. (2005) relataram teores de 11,2\% de ácido lático em silagem de milho. Todavia, Rodrigues et al. (2002) verificaram, na MS de silagens de milho, média de 9,9\% desse ácido orgânico, com mínimo de 6,5\% e máximo de $14,8 \%$.

Krizsan \& Randby (2006), conduzindo um trabalho sobre silagens de pasto, registraram valores de ácido lático na MS dessas silagens, com média igual a 4,9\%, mínimo de $0,22 \%$ e máximo $10,9 \%$. Para silagem de capimelefante, Ferrari Jr. \& Lavezzo (2001) relatam concentrações de 2,35 a 3,52\% desse ácido na MS; Andrade \& Melotti (2004) 2,4\% em silagem sem aditivo e, quando adicionaram uréia ao material, na proporção de $0,5 \%$, a média caiu para $1,05 \%$.

A produção de nutrientes digestíveis totais por hectare $(\mathrm{NDT} / \mathrm{ha})$ no $\mathrm{BCE}$ foi menor $(\mathrm{P}<0,05)$ que nos outros arranjos, que não diferiram entre si $(\mathrm{P}>0,05)$ (Figura 3$)$.

$\mathrm{Na}$ literatura, são escassos os trabalhos sobre produção de NDT por área, oriundos de silagens de milho, de capim-braquiária ou consórcio dessas duas culturas. Entretanto, pode-se fazer inferências sobre a produção de energia de alimentos por unidade de área multiplicando-se a produção de MS da área pela digestibilidade dessa matéria seca ou pela digestibilidade da matéria orgânica. O produto entre a produção de MS/ha e a digestibilidade da MS (em \%) dos dados de Obeid et al. (1992a) resulta em 6.449 kg de matéria seca digestível (MSD) por hectare. Aplicando-se esse produto para os dados de Obeid et al. (1992b), obtêm-se $7.139 \mathrm{~kg}$ de MSD/ha. Esses autores trabalharam com a metodologia in vitro para determinação da DMS. Para silagens de sorgo em cultivo exclusivo, Zago (2001) apresenta dados compilados de Santos (1996), nos quais a produção de NDT variou de 4.400 a $10.800 \mathrm{~kg} / \mathrm{ha}$.

A menor produção de NDT/ha no BCE deveu-se tanto ao menor teor de NDT na MS das silagens, quanto à menor produtividade por área do capim-braquiária em relação ao MCE e aos consórcios (M+2FBEL e M+BLAN). 


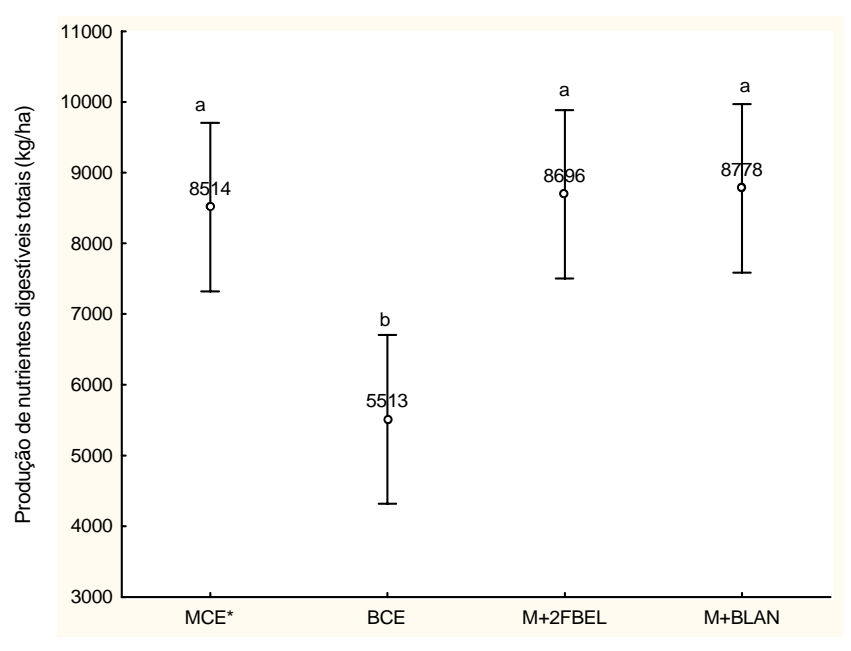

MCE $=$ milho em cultivo exclusivo

$\mathrm{BCE}=$ capim-braquiária em cultivo exclusivo

$\mathrm{M}+2 \mathrm{FBEL}=$ duas fileiras do capim-braquiária nas entrelinhas do milho

M+BLAN = capim-braquiária semeada a lanço nas entrelinhas do milho

Figura 3 - Nutrientes digestíveis totais por hectare (NDT/ha) nos diferentes arranjos de semeadura. As barras representam o intervalo de confiança de $95 \%$ e letras iguais indicam que os arranjos não diferiram entre si $(\mathrm{P}<0,05)$.

\section{Conclusões}

O cultivo de capim-braquiária e milho em consórcio proporciona maior produção de nutrientes por área em comparação ao capim-braquiária em cultivo exclusivo, independentemente do arranjo de semeadura. Silagens dessas forrageiras produzidas em consórcio apresentam melhores características qualitativas na matéria seca.

\section{Literatura Citada}

ANDRADE, S.J.T.; MELOTTI, L. Efeito de alguns tratamentos sobre a qualidade da silagem de capim-elefante cultivar Napier (Pennisetum purpureum, Schum). Brazilian Journal of Veterinary Research and Animal Science, v.41, n.6, p.409$415,2004$.

ASSOCIATION OF OFFICIAL ANALYTICAL CHEMISTRY AOAC. Official methods of analysis. 15.ed. Arlington: 1990. $1298 \mathrm{p}$.

BENACCHIO, S. Niveles de melaza en silo experimental de milho criollo (Sorghum vulgare). Agronomia Tropical, v.14, n.4, p.651-658, 1965.

CABRAL, L.S.; VALADARES FILHO, S.C.; DETMANN, E. et al. Consumo e digestibilidade dos nutrientes em bovinos alimentados com dietas à base de volumosos tropicais. Revista Brasileira de Zootecnia, v.35, n.6, p.2406-2412, 2006.

CAPPELLE, E.R.; VALADARES FILHO, S.C.; COELHO DA SILVA, J.F. et al. Estimativas do valor energético a partir de características químicas e bromatológicas dos alimentos. Revista Brasileira de Zootecnia, v.30, n.6, p.1837-1856, 2001.

CAVALCANTE, A.C.R.; PEREIRA, O.G.; VALADARES FILHO, S.C. et al. Dietas contendo silagem de milho (Zea mays L.) e feno de capim-tifton 85 (Cynodon spp.) em diferentes proporções para bovinos. Revista Brasileira de Zootecnia, v.33, n.6, p.2394-2402, 2004 (supl. 3).

CHIZZOTTI, M.L.; VALADARES FILHO, S.C.; VALADARES, R.F.D. et al. Consumo, digestibilidade e excreção de uréia e derivados de purinas em novilhas de diferentes pesos. Revista Brasileira de Zootecnia, v.35, n.4, p.1813-1821, 2006 (supl.).

CHIZZOTTI, F.H.M.; PEREIRA, O.G.; VALADARES FILHO, S.C. et al. Consumo, digestibilidade total e desempenho de novilhos nelore recebendo dietas contendo diferentes proporções de silagens de Brachiaria brizantha cv. marandu e de sorgo. Revista Brasileira de Zootecnia, v.34, n.6, p.2427-2436, 2005 (supl.).

CORRÊA, L.A.; CORDEIRO, C.A. Silagem de capim como estratégia de manejo intensivo de pastagens. São Carlos: EMBRAPA CPPSE, 2000. 6p. (Comunicado Técnico, 26)

COSTA, M.A.L.; VALADARES FILHO, S.C.; VALADARES, R.F.D. et al. Validação das equações do NRC (2001) para predição do valor energético de alimentos nas condições brasileiras. Revista Brasileira de Zootecnia, v.34, n.1, p.280-287, 2005.

COSTA, R.S.; NUSSIO, L.G.; CARNEVALLI, R.A. et al. Avaliação do teor de carboidratos solúveis em plantas de milho como parâmetro para determinação do ponto de colheita para a ensilagem. In: REUNIÃO ANUAL DA SOCIEDADE BRASILEIRA DE ZOOTECNIA, 39., 2001, Piracicaba. Anais... Piracicaba: Sociedade Brasileira de Zootecnia, 2001. (CD-ROM).

CYSNEIROS, C.S.S.; FRANCO, G.L.; ULHOA, C.J. et al. Efeito de enzimas fibrolíticas sobre a composição bromatológica de silagens de capins tropicais. Ciência Animal Brasileira, v.7, n.1, p.1-10, 2006.

EVANGELISTA, A.R.; GARCIA, R.; OBEID, J.A. et al. Consórcio milho-soja: rendimento forrageiro e teor de proteína bruta da forragem. Revista Brasileira de Zootecnia, v.20, n.6, p.572$577,1991$.

EVANGELISTA, A.R.; REZENDE, P.M.; MACIEL, G.A. Uso da soja Glycine max (L.) Merril na forma de forragem. Lavras: Editora UFLA, 2003. 36p. (Boletim de Extensão).

FANCElli, A.L.; DOURADO-NETO, D. Produção de milho. Guaíba: Agropecuária, 2000. 360p.

FERRARI JR., E.; LAVEZZO, W. Qualidade da silagem de capimelefante (Pennisetum purpureum Schum.) emurchecido ou acrescido de farelo de mandioca. Revista Brasileira de Zootecnia, v.30, n.5, p.1424-1431, 2001.

FERREIRA, J.J. Estágio de maturação ideal para ensilagem do milho e do sorgo. In: CRUZ, J.C.; PEREIRA FILHO, I.A.; RODRIGUES, J.A.S. et al. (Eds.) Produção e utilização de silagem de milho e sorgo. Sete Lagoas: Embrapa Milho e Sorgo, 2001. p.405-428.

GHISI, O.M.A.; PEDREIRA, J.V.S. Características agronômicas das principais Brachiaria. ssp. In: ENCONTRO SOBRE CAPINS DO GÊNERO BRACHIARIA, 1987, Nova Odessa. Anais... Nova Odessa, Instituto de Zootecnia, 1987. p.19-58.

HENRIQUE, A.; PERES, R.M.; FILHO, J.L.V.C. et al. Avaliação de três híbridos de milho (Zea mays L.) para produção de silagem. In: REUNIÃO ANUAL DA SOCIEDADE BRASILEIRA DE ZOOTECNIA, 31., 1994, Maringá. Anais... Maringá: Sociedade Brasileira de Zootecnia, 1994. p.343

HIGGINBOTHAM, G.E.; MULLER, S.C.; BOLSEN, K.K. et al. Effects of inoculants containing propionic acid bacteria on fermentation and aerobic stability of corn silage. Journal of Dairy Science, v.81, p.2185-2192, 1998.

JUNG, H.G.; DEETZ, D.A. Cell wall lignification and degradability. In: JUNG, H.G.; BUXTON, D.R.; HATFIELD, R.D. et al. (Eds.) Forage cell wall structure and digestibility. Madison: ASA/CSSA/SSSA, 1993. p.315-346. 
KRIZSAN, S.J.; RANDBY, A.T. The effect of fermentation quality on the voluntary intake of grass silage by growing cattle fed silage as sole feed. Journal of Animal Science, v.85, p.984-996, 2007.

KUNG JR., L.; SHAVER, R. [2001]. Interpretation and use of silage fermentation analysis reports. Focus on Forage, v.3, n.13, 2001. Disponível em: <http://www.uwex.edu/ces/crops/uwforage/ Fermentation.pdf $>$ Acesso em: 19/1/2007.

MAGALHÃES, A.L.R.; CAMPOS, J.M.S.; VALADARES FILHO, S.C. et al. Cana-de-açúcar em substituição à silagem de milho em dietas para vacas em lactação: desempenho e viabilidade econômica. Revista Brasileira de Zootecnia, v.33, n.5, p.1292-1302, 2004.

McCULLOUGH, M.E. Silage and silage fermentation. Feedstuffs, v.49, n.13, p.49-52, 1977

McDONALD, P.; HENDERSON, A.R.; HERON, S.J.E. The biochemistry of silage. 2.ed. Bucks: Chalcombe Publications, 1991. 340p

MELO, W.M.C.; Von PINHO, R.G.; CARVALHO, M.L.E M. et al. Avaliação de cultivares de milho para produção de silagem na região de Lavras - MG. Ciência e Agrotecnologia, v.23, n.1, p.31-39, 1999.

MOISIO, T.; HEIKOMEN, M. Lactic acid fermentation in silage preserved with formic acid. Animal Feed Science and Technology, v.47, n.1, p.107-124, 1994.

MURDOCH, J.C.; BALCH, D.A.; HOLDSWORTH, M.C. et al. The effect of chopping, lacerating and wilting of herbage on the chemical composition of silage. Journal British Grassland Society, v.10, n.2, p.181-186, 1975 .

NATIONAL RESEARCH COUNCIL - NRC. Nutrient requirements of dairy cattle. 7.ed. Washington, D.C.: National Academy Press, 2001. 381p.

NUSSIO, L.G. Volumosos suplementares na produção de bovinos de corte em pastagens. In: REUNIÃO ANUAL DA SOCIEDADE BRASILEIRA DE ZOOTECNIA, 38., Piracicaba, 2001. Anais... Piracicaba: Sociedade Brasileira de Zootecnia, 2001. p.253-275.

OBEID, J.A.; PEREIRA, O.G.; PEREIRA, D.H. et al. Níveis de proteína bruta em dietas para bovinos de corte: consumo, digestibilidade e desempenho produtivo. Revista Brasileira de Zootecnia, v.35, n.6, p.2434-2442, 2006

OBEID, J.A.; GOMIDE, J.A.; CRUZ, M.E. et al. Silagem consorciada de milho (Zea mays) com leguminosas: produção e composição bromatológica. Revista Brasileira de Zootecnia, v.21, n.1, p.33-38, 1992 .

OBEID, J.A.; GOMIDE, J.A.; CRUZ, M.E. Qualidade e valor nutritivo de silagem consorciada de milho (Zea mays) com soja anual (Glycine max. (L.) Merrill). Revista Brasileira de Zootecnia, v.21, n.1, p.39-44, 1992.

OLIVEIRA, T.K.; MACEDO, R.L.G.; SANTOS, I.P.A. et al. Produtividade de Brachiaria brizantha (Hochst. ex A. Rich.) Stapf cv. Marandu sob diferentes arranjos estruturais de sistema agrossilvipastoril com eucalipto. Ciência Agrotécnica, v.31, n.3, p.748-757, 2007.

OLIVEIRA, J.S. Manejo do silo e utilização da silagem de milho e sorgo. In: CRUZ, J.C.; PEREIRA FILHO, I.A.; RODRIGUES, J.A.S. et al. (Eds.) Produção e utilização de silagem de milho e sorgo. Sete Lagoas: Embrapa Milho e Sorgo, 2001. p. $473-518$.

OLIVEIRA, O.C.; OLIVEIRA, I.P.; FERREIRA, E. et al. Response of degraded pastures in the Brazilian Cerrado to chemical fertilization. Pasturas Tropicales, v.13, n.1, p.14-18, 2001.

PINA, D.S.; VALADARES FILHO, S.C.; DETMANN, E. et al. Efeitos de indicadores e dias de coleta na digestibilidade dos nutrientes e nas estimativas do valor energético de alimentos para vacas alimentadas com diferentes fontes de proteína. Revista Brasileira de Zootecnia, v.35, n.6, p.2461-2468, 2006.

POSSENTI, R.A.; FERRARI JR., E.; BUENO, M.S. et al. Parâmetros bromatológicos e fermentativos das silagens de milho e girassol. Ciência Rural, v.35, n.5, p.1185-1189, 2005.
RANJIT, N.K.; KUNG JR., L. The effect of Lactobacillus buchneri, Lactobacillus plantarum, or a chemical preservative on the fermentation and aerobic stability of corn silage. Journal of Dairy Science, v.83, n.3, p.526-535, 2000.

REIS, R.A.; COAN, R.M. Produção e utilização de silagens de gramíneas. In: COLÉGIO BRASILEIRO DE NUTRIÇÃO ANIMAL, 3., 2001, Goiânia. Anais... Goiânia: 2001. p. $91-120$.

ROCHA, K.D.; PEREIRA, O.G.; VALADARES FILHO, S.C. et al. Valor nutritivo de silagens de milho (Zea mays L.) produzidas com inoculantes enzimo-bacterianos. Revista Brasileira de Zootecnia, v.35, n.2, p.389-395, 2006.

ROCHA, F.C.; GARCIA, R.; FREITAS, A.W.P. et al. Consumo e digestibilidade de dietas formuladas com diferentes níveis de casca de café para vacas em lactação. Revista Brasileira de Zootecnia, v.35, n.5, p.2154-2162, 2006.

RODRIGUES, P.H.M.; RUZANTE, J.M.; SENATORE, A.L. et al. Avaliação do uso de inoculantes microbianos sobre a qualidade fermentativa e nutricional da silagem de milho. Revista Brasileira de Zootecnia, v.33, n.3, p.538-545, 2004.

RODRIGUES, P.H.M.; PEDROSO, S.B.G.; MELOTTI, L. et al. Estudo comparativo de diferentes tipos de silos sobre a composição bromatológica e perfil fermentativo da silagem de milho. Acta Scientiarum, v.24, n.4, p.1127-1132, 2002.

ROTZ, C.A.; MUCK, R.E. Changes in forage quality during harvest and storage. In: FAHEY JR., G.C.; COLLINS, M.; MERTENS, D.R. et al. (Eds.) Forage quality, evaluation and utilisation. Madison: ASA/CSSA/SSSA, 1994. p.828-868.

SANTOS, E.D.G.; PAULINO, M.F.; QUEIROZ, D.S. Avaliação de pastagem diferida de Brachiaria decumbens stapf: características químico-bromatológicas da forragem durante a seca. Revista Brasileira de Zootecnia, v.33, n.1, p.203$213,2004$.

SILVA, B.C.; PEREIRA, O.G.; PEREIRA, D.H. et al. Consumo e digestibilidade aparente total dos nutrientes e ganho de peso de bovinos de corte alimentados com silagem de Brachiaria brizantha e concentrado em diferentes proporções. Revista Brasileira de Zootecnia, v.34, n.3, p.1060-1069, 2005.

SILVA, D.J.; QUEIROZ, A.C. Análise de alimentos (métodos químicos e biológicos). 3.ed. Viçosa, MG: Editora UFV, 2002. $235 \mathrm{p}$.

SILVA, L.F.P.; MACHADO, P.F.; FRANCISCO JR., J.C. et al. Características agronômicas e digestibilidade "in situ" da fração volumosa de híbridos de milho para silagem. Scientia Agrícola, v.56, n.1, p.171-184, 1999.

SILVA, A.W.L.; ALMEIDA, M.L.; MAFRA, A.L. et al. Avaliação de híbridos e variedades de milho (Zea mays L.) para ensilagem. III. Características químico-bromatológicas da silagem. In: REUNIÃO ANUAL DA SOCIEDADE BRASILEIRA DE ZOOTECNIA, 31., 1994, Maringá. Anais... Maringá: Sociedade Brasileira de Zootecnia, 1994. p.357.

SILVEIRA, A.C. Técnicas para produção de silagem. In: SIMPÓSIO SOBRE MANEJO DE PASTAGEM, 2., 1975, Piracicaba. Anais... Piracicaba: Fundação de Estudos Agrários Luiz de Queiroz, 1975.p.156-185.

SNIFFEN, C.J.; O'CONNOR, J.D.; Van SOEST, P.J. et al. A net carbohydrate and protein system for evaluation cattle diets. II. Carbohydrate and protein availability. Journal of Animal Science, v.70, n.11, p.3562-3577, 1992.

TOSI, P.; MATOS, W.R.S.; TOSI, H. et al. Avaliação do capim elefante (Pennisetum purpureum schum.) Cultivar Taiwam A-148, ensilado com diferentes técnicas de redução de umidade. Revista Brasileira de Zootecnia, v.28, n.5, p.947-954, 1999.

TOWNSEND, C.R.; COSTA, N.L.; PEREIRA, R.G. Renovação de pastagens degradadas em consórcio com milho na Amazônia Ocidental. In: CONGRESSO NACIONAL DE MILHO E SORGO, 18., 2000, Uberlândia, Anais... Uberlândia: Associação Brasileira de Milho e Sorgo, 2000. (CD-ROM). 
Van SOEST, P.J. Nutritional ecology of the ruminant. 2.ed. Ithaca: Cornell University Press, 1994. 476p.

VILELA, D. Sistema de conservação de forragem. 1) silagem Coronel Pacheco: EMBRAPA CNPGL, 1985. 15p. (Boletim de Pesquisa, 11).

WEISS, W.P.; CONRAD, H.R.; PIERRE, R.S. A theoretically-based model for predicting total digestible nutrient values of forages and concentrates. Animal Feed Science and Technology, v.39, p.95-100, 1992.
WERNERSBACH FILHO, H.L.; CAMPOS, J.M.S.; ASSIS, A.J. et al. Variáveis ruminais, concentração de uréia plasmática e excreções urinárias de nitrogênio em vacas leiteiras alimentadas com concentrado processado de diferentes formas. Revista Brasileira de Zootecnia, v.35, n.3, p.1236-1241, 2006 (supl.). ZAGO, C.P. Silagem de sorgo de alto valor nutritivo. In: CRUZ, J.C.; PEREIRA FILHO, I.A.; RODRIGUES, J.A.S. et al. (Eds.) Produção e utilização de silagem de milho e sorgo. Sete Lagoas: Embrapa Milho e Sorgo, 2001. p.519-544. 